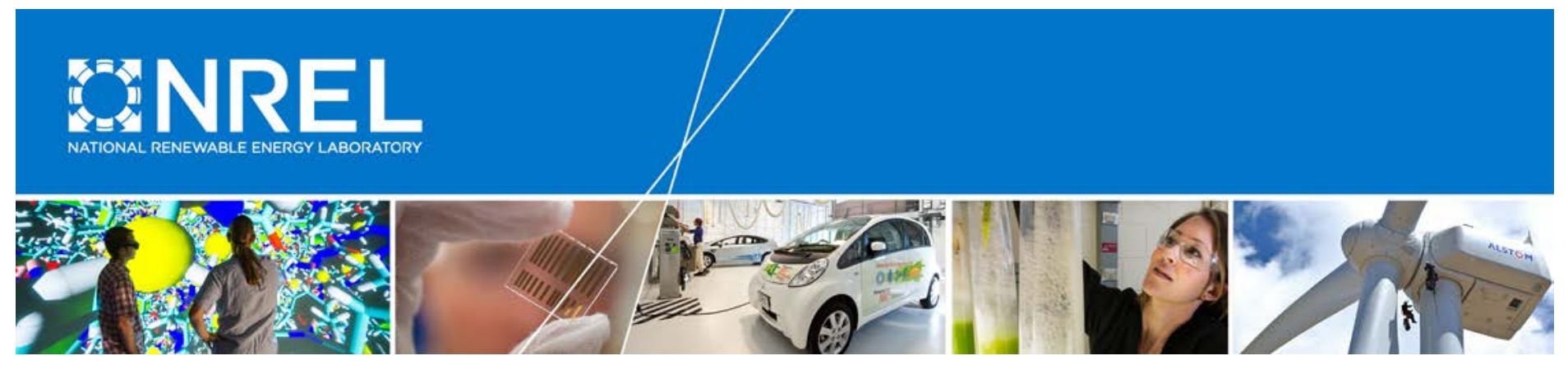

\title{
Water Impacts of High Solar PV Electricity Penetration
}

Jordan Macknick and Stuart Cohen National Renewable Energy Laboratory (NREL)

NREL is a national laboratory of the U.S. Department of Energy Office of Energy Efficiency \& Renewable Energy Operated by the Alliance for Sustainable Energy, LLC

This report is available at no cost from the National Renewable Energy Laboratory (NREL) at www.nrel.gov/publications.

\section{Technical Report}

NREL/TP-6A20-63011

September 2015 


\section{Water Impacts of High Solar PV Electricity Penetration}

Jordan Macknick and Stuart Cohen National Renewable Energy Laboratory (NREL)

Prepared under Task No. SM13.5002
NREL is a national laboratory of the U.S. Department of Energy Office of Energy Efficiency \& Renewable Energy Operated by the Alliance for Sustainable Energy, LLC

This report is available at no cost from the National Renewable Energy Laboratory (NREL) at www.nrel.gov/publications.

\section{Technical Report}

NREL/TP-6A20-63011

September 2015

Contract No. DE-AC36-08GO28308
National Renewable Energy Laboratory 15013 Denver West Parkway

303-275-3000 • www.nrel.gov 


\title{
NOTICE
}

This report was prepared as an account of work sponsored by an agency of the United States government. Neither the United States government nor any agency thereof, nor any of their employees, makes any warranty, express or implied, or assumes any legal liability or responsibility for the accuracy, completeness, or usefulness of any information, apparatus, product, or process disclosed, or represents that its use would not infringe privately owned rights. Reference herein to any specific commercial product, process, or service by trade name, trademark, manufacturer, or otherwise does not necessarily constitute or imply its endorsement, recommendation, or favoring by the United States government or any agency thereof. The views and opinions of authors expressed herein do not necessarily state or reflect those of the United States government or any agency thereof.

This report is available at no cost from the National Renewable Energy Laboratory (NREL) at www.nrel.gov/publications.

Available electronically at SciTech Connect http:/www.osti.gov/scitech

Available for a processing fee to U.S. Department of Energy and its contractors, in paper, from:

\author{
U.S. Department of Energy \\ Office of Scientific and Technical Information \\ P.O. Box 62 \\ Oak Ridge, TN 37831-0062 \\ OSTI http://www.osti.gov \\ Phone: 865.576.8401 \\ Fax: 865.576.5728 \\ Email: reports@osti.gov
}

Available for sale to the public, in paper, from:

\author{
U.S. Department of Commerce \\ National Technical Information Service \\ 5301 Shawnee Road \\ Alexandria, VA 22312 \\ NTIS http://www.ntis.gov \\ Phone: 800.553 .6847 or 703.605 .6000 \\ Fax: 703.605.6900 \\ Email: orders@ntis.gov
}




\section{Acknowledgments}

This work was funded through the Solar Energy Technologies Office of the U.S. Department of Energy. The authors would like to thank the following individuals for their thoughtful comments, input, and review of the document in its various stages: Geoff Klise (Sandia National Laboratories); Laura Vimmerstedt, Ariel Miara, Garvin Heath, and Dave Mooney (NREL). The authors also appreciate the graphical contributions of Billy Roberts (NREL) and the editorial support of Kendra Palmer (NREL). 


\section{Introduction}

The electricity sector is the largest withdrawer of freshwater in the nation (Kenny et al. 2009; Maupin et al. 2014). The dominant use of water in the electricity sector is for power plant cooling. As a result of elevated water temperatures or lack of available water, power plants in various regions throughout the United States have had to curtail generation or shut down, impacting regional energy security (U.S. DOE 2013; Rogers et al. 2013). Concerns over water availability in the past have affected decisions on where power plants could be built and what types of cooling systems they could employ (Averyt et al. 2011; Rogers et al. 2013). Certain types of energy sources used to produce electricity, in particular non-thermal photovoltaic (PV) and wind technologies, require little to no water use for operations (Macknick et al. 2012a). These types of energy technologies can be deployed in water-stressed areas without risk of curtailed generation during drought.

Water usage in this effort refers to two metrics: "withdrawals," or water removed from ground or diverted from a source for use, and "consumption," referring to the amount of water that is evaporated, transpired, incorporated into products or crops, or otherwise removed from the immediate water environment (Kenny et al. 2009). Water withdrawal and consumption metrics can both be used to evaluate potential energy sector impacts and vulnerabilities in the context of existing water resource availability. Water availability must be sufficient to support water withdrawals, and water consumption can affect downstream water users.

Thermal energy technologies can reduce water withdrawal and consumption rates through a variety of methods. Natural gas or gasified coal, for example, can be combusted in higher efficiency configurations such as a combined cycle power plant, which results in lower water requirements (Grubert et al. 2012). Recirculating cooling systems reduce water withdrawals when compared with once-through cooling systems, although water consumption would likely increase (Macknick et al. 2012a). Dry cooling technologies have substantially lower water withdrawal and consumption requirements than recirculating and once-through cooling systems, but can have higher installed and operating costs in addition to having lower efficiencies (US EPA, 2011). Finally, in many cases water demands can be met by using alternative non-fresh sources of water, such as shallow brackish groundwater or municipal wastewater, although this utilization could also lead to an increase in costs (Tidwell et al. 2013a).

Prior studies have evaluated the water impacts of electricity sector futures, including under "lowcarbon scenarios," although many of these studies have limited spatial resolution and have not explicitly addressed scenarios of high solar penetration (Chandel et al. 2011; Roy et al. 2012; van Vliet et al. 2012; Macknick et al. 2012b; Clemmer et al. 2013; Tidwell et al. 2013b; Macknick et al. 2015). Electricity capacity expansion models often lack an adequate level of geographic resolution in the electricity sector to meet spatial scales relevant for water resource management. The Department of Energy's SunShot Initiative Study considered high levels of solar energy penetration and briefly discussed water impacts (U.S. DOE 2012). However, the SunShot study was restricted to water consumption only, and only on a national scale. This work provides greater regional resolution of water resource impacts and constraints of high solar penetration scenarios. 
This analysis provides a detailed national and regional description of the water-related impacts and constraints of high solar electricity penetration scenarios in the U.S. in 2030 and 2050. A modified version of the Regional Energy Deployment System (ReEDS) model that incorporates water resource availability and costs as a constraint in each of its 134 Balancing Area (BA) regions was utilized to explore national and regional differences in water use impacts and solar deployment locations under different solar energy cost and water availability scenarios (Macknick et al. 2015). Water resource availability and cost data are from recently completed research at Sandia National Laboratories (Tidwell et al. 2013a). Scenarios analyzed include two business-as-usual solar energy cost cases, one with and one without considering available water resources, and four solar energy cost cases that meet the SunShot cost goals (i.e., $\$ 1 /$ watt for utility-scale PV systems), with varying levels of water availability restrictions. This analysis provides insight into the role solar energy technologies have in the broader electricity sector under scenarios of water constraints. 


\section{Methods}

The authors utilized a modified version of the ReEDS model that incorporates water resource availability and costs as constraints (Macknick et al. 2015). Six scenarios were evaluated that varied solar energy technology costs and water resource availability.

\subsection{ReEDS Model Overview}

The ReEDS model estimates the types and locations of future electricity generation and transmission capacity expansion along with seasonal and diurnal electricity dispatch over a period of 2010-2050 (Short et al. 2011). All major generating technologies are represented, including coal, natural gas combined cycle (GasCC), natural gas combustion turbine (GasCT), nuclear, hydro, wind, solar, geothermal, and biopower, as well as storage technologies. Generation capacity must meet requirements for regional electricity demand, operating reserves, and planning reserves. Spatial resolution is high for a capacity expansion model; electricity demand is satisfied in 134 BAs connected by an aggregated transmission system of $\sim 300$ lines, and wind and solar resources are defined in 356 resource regions. ReEDS uses a simplified dispatch that optimizes power output and operating reserves in 17 time slices, four for each season and one "superpeak" representing the top 40 hours of demand in a year. ReEDS also incorporates existing national and state energy policies.

ReEDS is a well-established tool that has been utilized for a variety of electricity system analyses examining high regional and national penetration of different types of renewable resources, impacts of natural gas price fluctuations, as well as for impacts of clean energy scenarios on water resources (U.S. DOE 2010; Logan et al. 2012; Macknick et al. 2012b; NREL 2012; U.S. DOE 2012; Clemmer et al. 2013).

For this analysis, a modified version of the ReEDS model was used that i) incorporates cost, performance, and water use characteristics of different fuel technology and cooling system combinations and ii) includes consideration of water resource availability as a necessary condition for new power plant builds.

Cooling systems implemented in the ReEDS model fall into four categories: once-through, pond, recirculating, and dry cooling systems. Individual power plant cooling systems are derived from a database developed by a team led by the Union of Concerned Scientists, which built upon DOE, private industry, and publicly available sources (Union of Concerned Scientists 2012). Within each ReEDS BA, existing generation capacity by fuel type is disaggregated into fuelcooling system categories based on 2008 generation data from the database and from updates on newer power plants acquired via internet searches. In cases where the database does not report cooling systems for certain fuel-types within a particular BA and no other information is available, the cooling system makeup for the fuel-type with most generation in that PCA is applied.

Cooling systems modeled in ReEDS have different capital cost, O\&M cost, performance, and water use characteristics. Input data to the ReEDS model provide cost and performance data for new power plants assuming they are built with recirculating cooling systems (Black and Veatch 2012). The ReEDS model uses a series of capital cost and performance multipliers to modify cost and performance input data based on cooling system type (Macknick et al. 2015).Water 
withdrawal and consumption rates for fuel technology cooling system combinations are defined in terms of volumes of water per unit of electricity generation (e.g., gallons per MWh). National values are applied to each BA region.

Operational water use requirements can vary greatly depending on fuel type, power plant type, and cooling system (Macknick et al. 2012a). Figure 1 highlights water withdrawal and consumption rates for a variety of power plant types and cooling systems. As shown, thermal power plants using once-through cooling withdraw far more water for every megawatt-hour of electricity generated than do plants using recirculating cooling systems. For water consumption, however, once-through cooling has lower demands than recirculating systems. Dry cooling technologies can substantially reduce both water withdrawal and consumption for thermal plants, yet have limited deployment due to higher costs and lower efficiencies (U.S. EPA 2011). Nonthermal renewable energy technologies, such as PV and wind, do not require water for cooling and thus have very low water use intensities. Wind plants require effectively no water for operations, while PV can use a relatively small amount in some locations, primarily for washing panels.

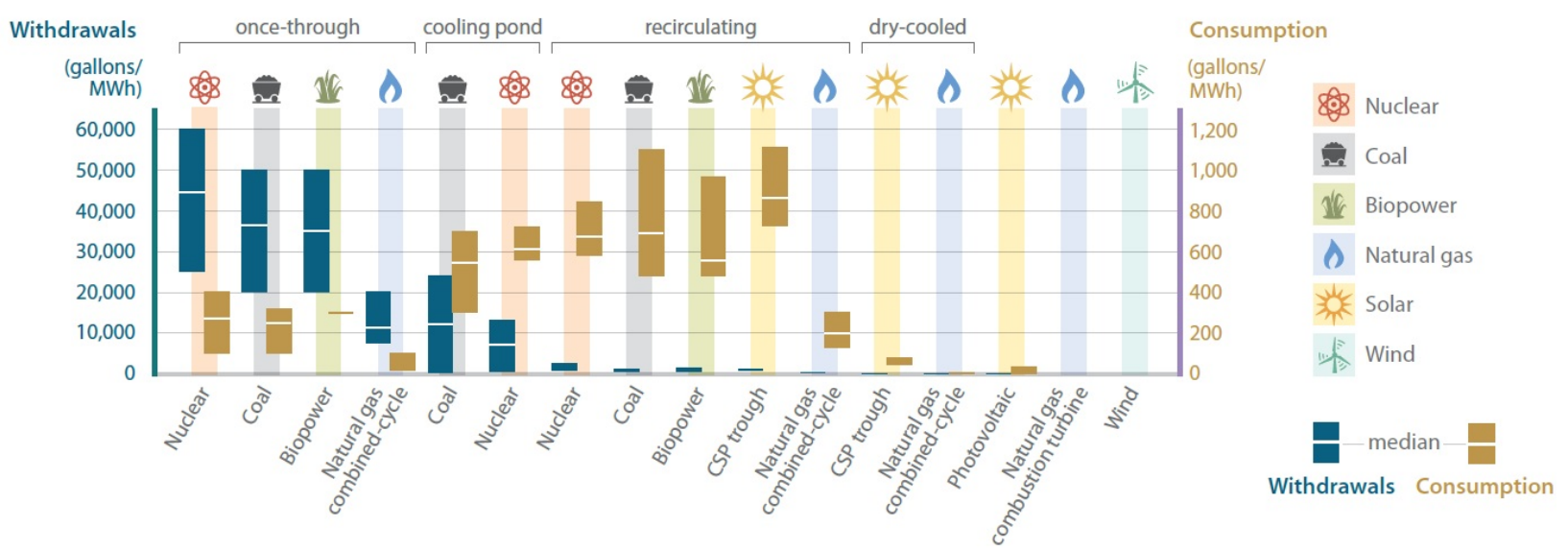

Figure 1. Water use rates for various types of power plants (Averyt et al. 2011)

Water availability constraints have been implemented in the model for each BA region. In order for new electric generation capacity to be built, sufficient water access must be purchased to meet the water requirements of the fuel technology-cooling system combination and the size of the facility. Sufficient water access is defined as enough water for an electric generator to operate at full capacity for an entire year. The ReEDS model calculates actual water withdrawals and consumption separately from the purchases of water access.

\subsection{Water Availability and cost data}

Each BA has unique water rights availability and cost for up to five resource categories: unappropriated freshwater, appropriated freshwater (Western United States only), fresh groundwater, brackish groundwater, and wastewater. Water rights availability data were developed in partnership with Sandia National Laboratories (Tidwell et al. 2013a). Water availability metrics also include projected growth in non-thermoelectric water demand to 2035 to provide an indication of future water availability, given competing demands. Multiple types of water resources can be purchased to meet the demand for new generation capacity. Water access 
of retiring power plants are returned to the pool of available water rights for new power plants at the price of appropriated water rights.

Costs associated with utilizing each of the five sources of water can vary geographically. Water cost information was designed to establish a consistent and comparable measure of cost to deliver water of potable quality to the point of use in the electric sector. Costs categories include capital and operating and maintenance (O\&M) costs. Capital costs include the purchase of water rights as well as the construction of groundwater wells, conveyance pipelines, and water treatment facilities, as necessary. O\&M costs include expendables (e.g., chemicals, membranes), labor, waste disposal as well as the energy to lift, move and treat the water.

Further information, including a full treatment of source data and methods for developing water availability metrics can be found in Tidwell et al. (2013a). More specific information about water resource modifications in the ReEDS model can be found in Macknick et al. (2015).

\subsection{Other key ReEDS data and Assumptions}

ReEDS input data and assumptions implemented in this analysis are largely derived from a ReEDS version updated from that used in the NREL Renewable Electricity Futures (REF) report and solar energy costs from the SunShot study (Mai et al. 2012; NREL 2012; U.S. DOE 2012). Technology cost and performance estimates use REF incremental technology improvement (ITI) projections based on Black \& Veatch data, aside from solar cost data (Mai et al. 2012). Transmission cost and financing assumptions are also identical to REF. Natural gas, coal, and uranium price projections are exogenously defined using the U.S. Energy Information Administration (USEIA) Annual Energy Outlook (AEO) 2013 Early Release (U.S. EIA 2013).

Solar energy costs are derived from the DOE SunShot Initiative Study (U.S. DOE, 2012). Wind and geothermal resources are the same as in the REF report. Biomass resources have been updated for the Billion Ton Update study (U.S. DOE, 2011). Hydropower resources have been updated to include preliminary resource assessments from Oak Ridge National Laboratory (ORNL) (Hadjerioua et al. 2012; Hadjerioua et al. 2013; Zhang et al. 2013).

Retirements of nuclear- and fossil-based facilities are based on proposed and lifetime retirements as described by Ventyx and M.J. Bradley along with capacity factor-based coal-fired capacity retirements, where coal-fired capacity that operates below a certain capacity factor threshold is retired (Saha 2013; Ventyx 2013).

\subsection{Scenario Analysis}

Six scenarios from 2010 to 2050 were analyzed to explore the regional and national sensitivity of solar penetration to two varying conditions: solar energy costs and water resource availability. Two base solar energy cost scenarios were analyzed, one that does not consider water resources as a constraint (Base-NR) and one that considers water constraints and includes all available water resource types (Base-AR). Four improved solar energy cost scenarios were analyzed, with varying levels of water constraints. SS-NR does not consider water resources as a constraint, SSAR considers water constraints and includes all available water resource types, SS-NF considers water constraints and does not allow new electricity generating technologies to utilize new sources of freshwater (but water rights that become available from existing power plants retiring 
are allowed), and SS-NFNR considers water constraints but does not allow new freshwater sources or retired water rights to be utilized. Table 1 shows scenarios considered.

Table 1. Scenario Matrix Considered in this Analysis

\begin{tabular}{|l|l|l|l|}
\hline Scenario & $\begin{array}{l}\text { Water Rights } \\
\text { Constraint }\end{array}$ & $\begin{array}{l}\text { Water Rights } \\
\text { Available }\end{array}$ & Solar Energy Cost \\
\hline Base-NR & No & N/A & Base \\
\hline Base-AR & Yes & All & Base \\
\hline SS-NR & No & N/A & Improved \\
\hline SS-AR & Yes & All & Improved \\
\hline SS-NF & Yes & No new freshwater & Improved \\
\hline SS-NFNR & Yes & Nources & \\
\hline & & $\begin{array}{l}\text { No new freshwater } \\
\text { sources; no retired } \\
\text { water availability }\end{array}$ & \\
\hline
\end{tabular}




\section{Results}

\subsection{National Electricity Sector Results}

Under the two base solar energy cost scenarios, electricity capacity grows by 2050 to over 1,730 $\mathrm{GW}$, with similar percentages of fuel technologies (Figure 2). Under the four improved cost scenarios, electricity capacity grows to around 1,800 GW, with increases in PV deployment providing most of the capacity additions, with smaller capacity additions for natural gas combined cycle (NGCC) power plants and natural gas combustion turbine (NGCT) power plants. Wind capacity declines by around $10 \mathrm{GW}$ in the improved cost scenarios. Natural gas combined cycle (NGCC) power plants provide the plurality of electric capacity ( $\sim 60 \mathrm{GW})$ by the year 2050 under all scenarios. Solar PV capacity in 2050 is approximately $380 \mathrm{GW}$ under the base case cost assumptions, and approximately $440 \mathrm{GW}$ under the SunShot cost scenarios. National Solar PV capacity in 2050 under the SunShot cost scenarios are all within $1.5 \%$ of each other, with the most restrictive water case (SS-NFNR) providing a slightly higher level of PV capacity. Under the base cost assumptions, PV technologies provide approximately $11 \%$ of total electricity generation in 2050, and under the improved cost scenarios, PV technologies provide approximately $12 \%$ of total electricity generation in 2050 . PV produces the fourth-highest amount of electricity in all cases. In 2050 for all scenarios, natural gas combined cycle technologies produce $35-36 \%$ of total electricity generation, wind energy technologies produce $23-24 \%$ of total electricity generation, and coal technologies produce around $19 \%$ of total electricity generation.

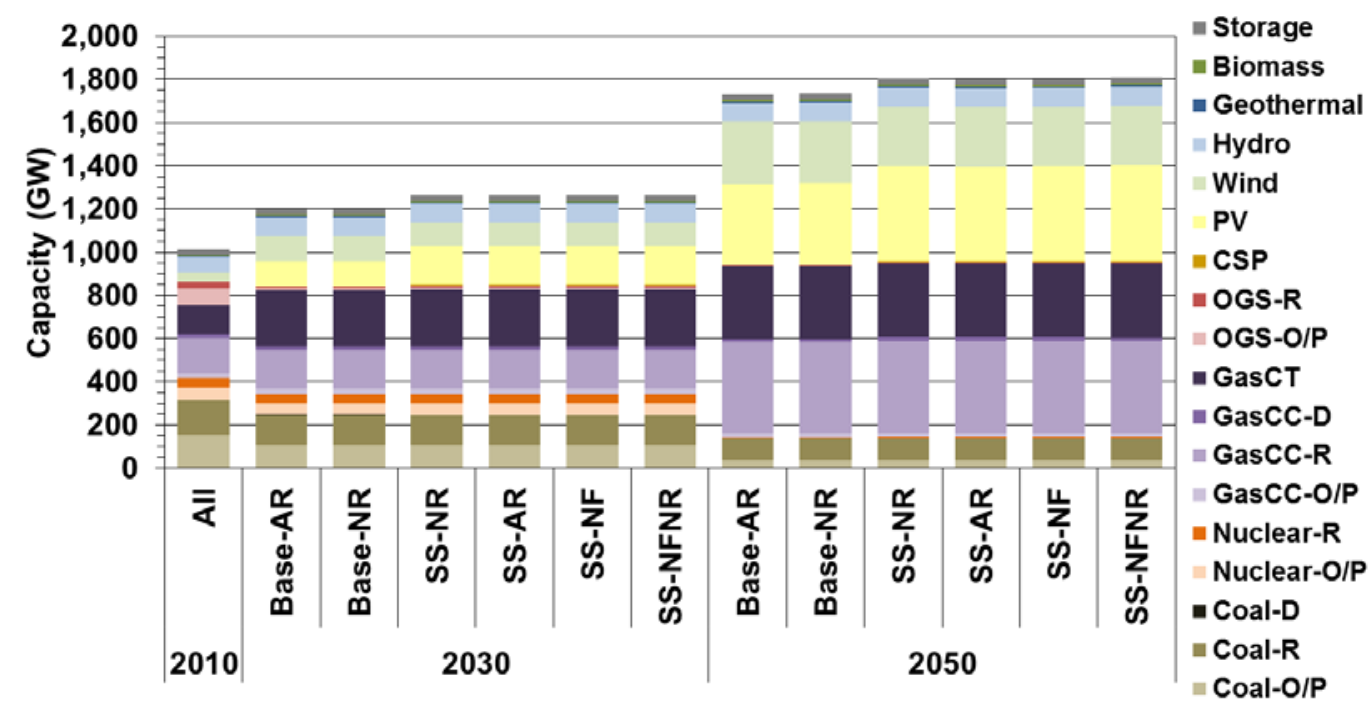

Figure 1. National electricity capacity by fuel type and cooling system in 2010, 2030, and 2050

$\mathrm{GW}=$ Gigawatts; $\mathrm{OGS}=\mathrm{Oil}$, gas steam technologies; $\mathrm{R}=$ Recirculating cooling; $\mathrm{O} / \mathrm{P}=$ Once-through and pond cooling; $\mathrm{D}=$ Dry cooling; $\mathrm{CT}=$ Combustion turbine; $\mathrm{CC}=$ Combined Cycle. 


\subsection{Regional Electricity Sector Results}

Although national levels of deployment are similar across scenarios, regional differences in where solar PV is deployed can be substantial and can highlight areas where solar PV can have the greatest impact in meeting electricity loads with lower impacts on water resources. Regional differences in electricity capacity and generation can translate to regional differences in water impacts.

In 2050 under the Base-AR scenario, where base case solar energy costs are utilized and all water rights are considered, PV installation is concentrated in the U.S. Southeast and the U.S. Southwest (Figure 3).

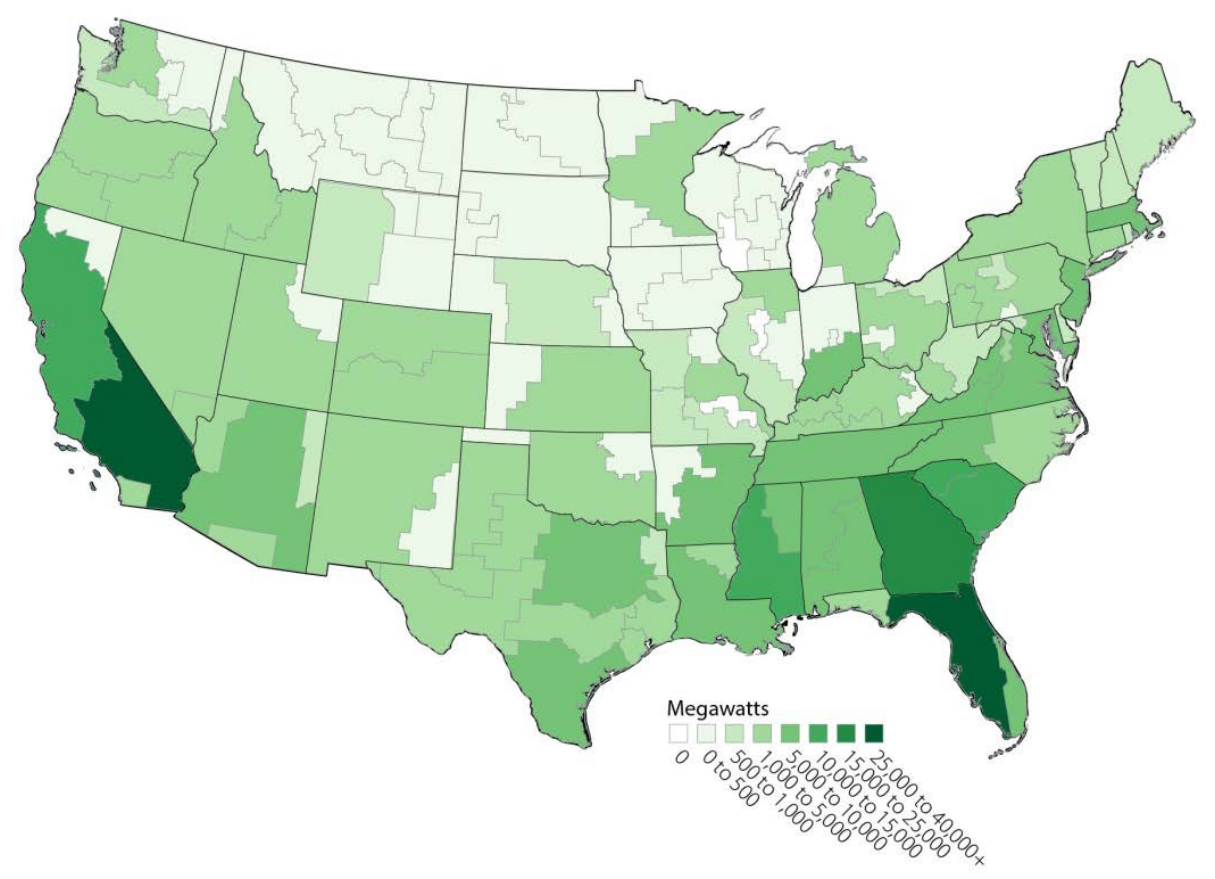

Figure 3. Cumulative PV installations (GW) in $\mathbf{2 0 5 0}$ for the Base-AR scenario

The inclusion of improved solar energy costs can lead to important regional differences in where new PV capacity is installed. PV installations in the SS-AR scenario (where improved solar costs are used and all water rights are considered) are approximately $65 \mathrm{GW}$ greater than those in the Base-AR scenario (where base case solar costs are used and all water rights are considered), yet the location of these installations occur in a variety of locations in the United States (Figure 4). New installations are dominated by the north-central and north-eastern parts of the United States, as well as California, Texas, and parts of the Southeast. 


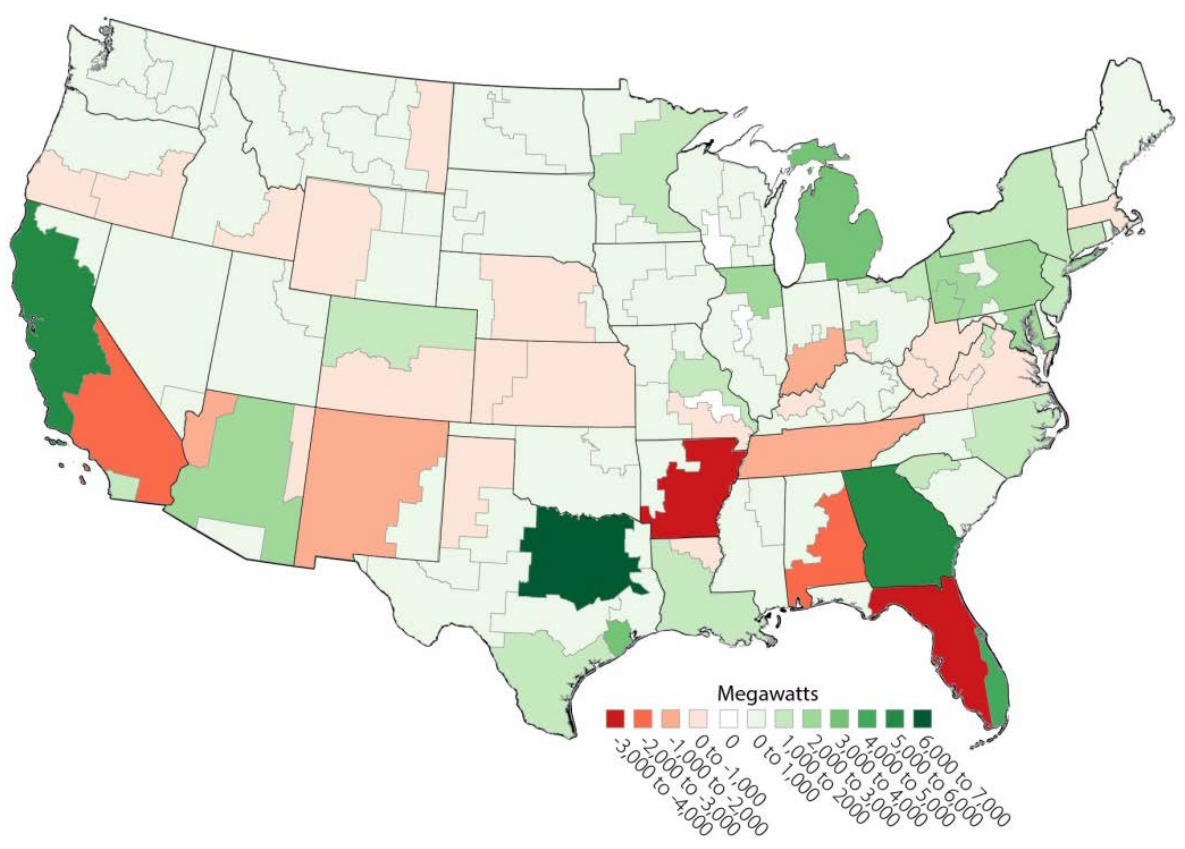

Figure 4. Comparison of installed PV capacity in 2050 between Base-AR and SS-AR by MW installed

The percentage change in installations is highest in the northern parts of the United States as well as Texas (Figure 5). Lower percentage increases in installations are seen in the U.S. Southeast and the U.S. Southwest, due to the already relatively high level of deployment in these regions.

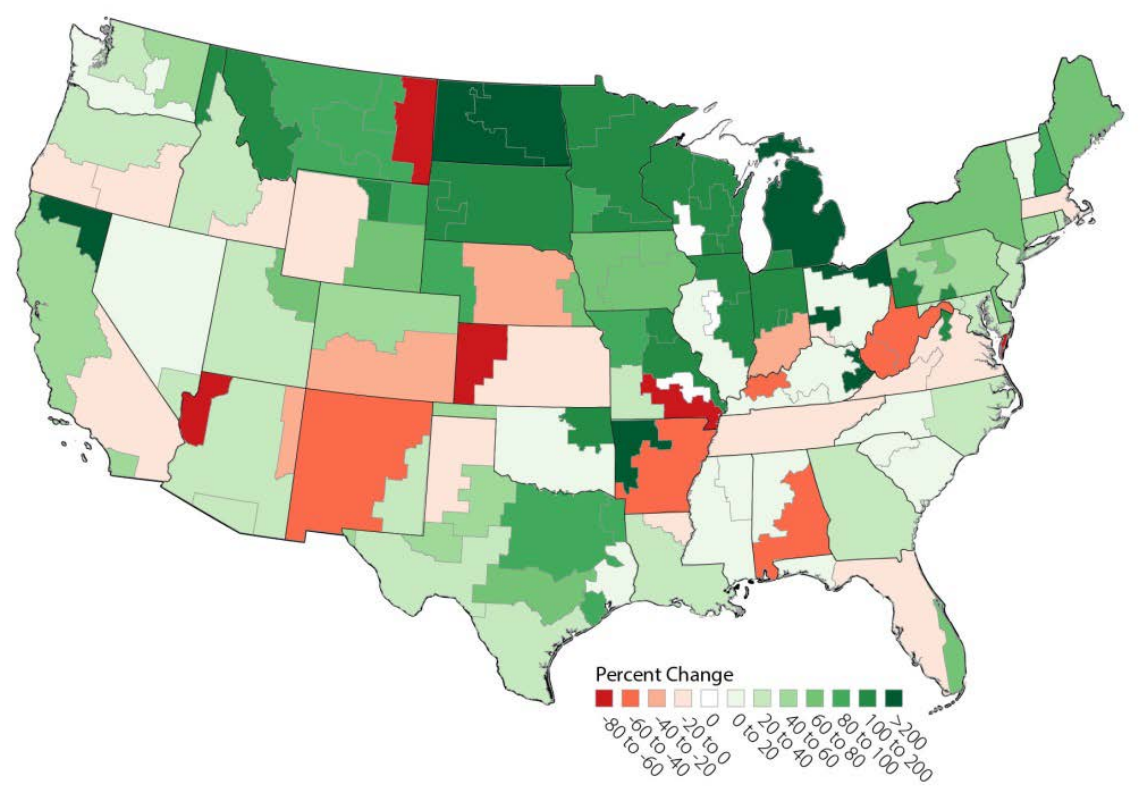

Figure 5. Comparison of installed PV capacity in 2050 between Base-AR and SS-AR by percent differences 
Water availability constraints can also lead to regional and national differences in PV installed capacity in 2050. The SS-NFNR scenario (which includes improved solar costs, no new freshwater resources and no retired water availability) shows approximately $6 \mathrm{GW}$ more of PV capacity than the SS-AR scenario (which includes improved solar costs and all water resource types) in 2050, with most of the increase in PV capacity centered in the U.S. Southeast, where water availability is often not considered a major concern (Figure 6). This suggests that strict water use rules, such as those in the SS-NFNR, could lead to greater increases in PV deployment in what are generally considered to be water rich areas than in water-stressed areas. High levels of population growth can lead to large increases in energy demands, which must be met by additional electric capacity; when water availability is restricted, low-water energy technologies (e.g., PV) can have advantages over water-intensive technologies. Water restrictions that affect thermal generators also affect the location of solar deployment, and Figure 6 highlights the change in location of solar deployment from Florida to Alabama and Georgia that results from the large dependency of the latter states on water-based generation and the thermal retirements that occur.

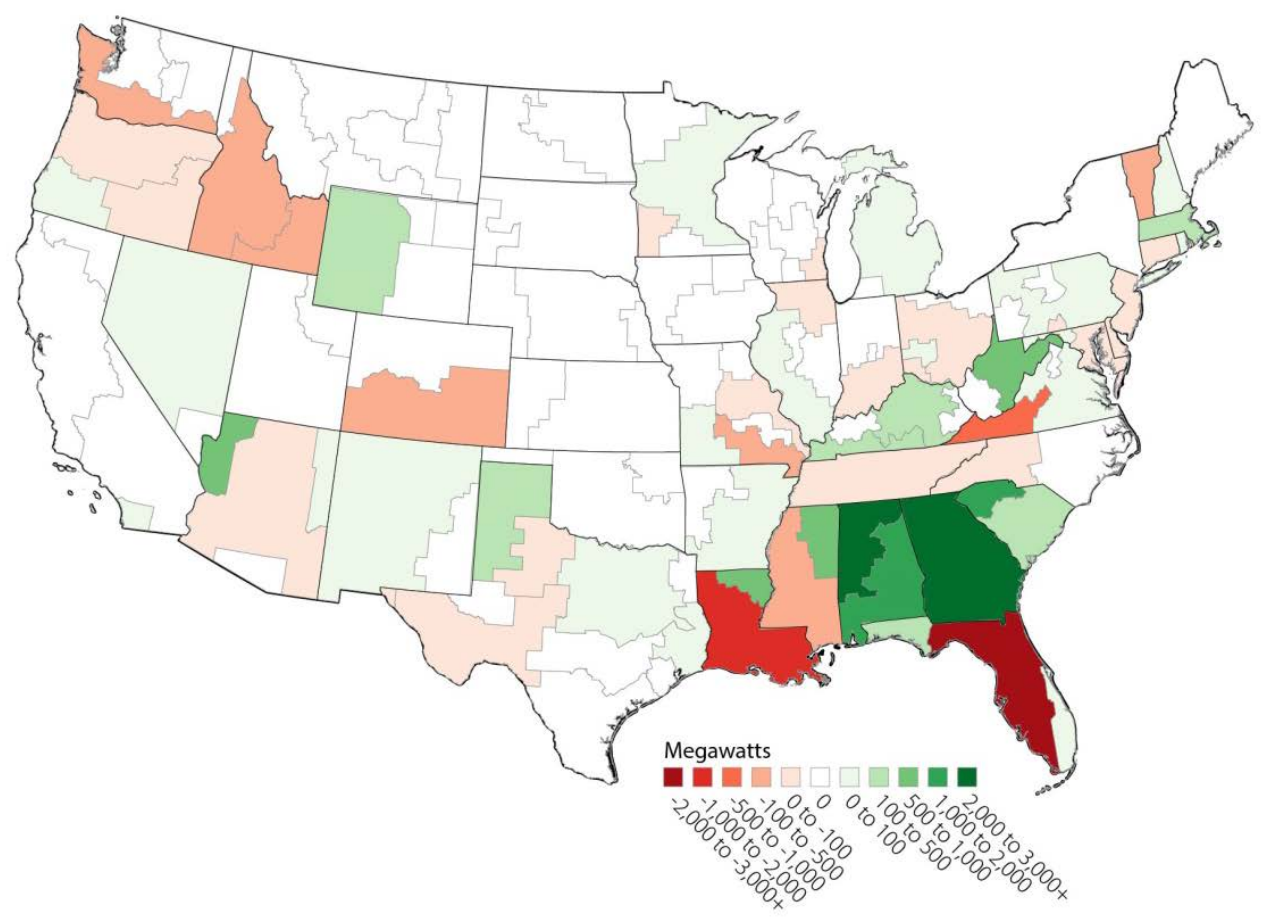

Figure 6. Comparison of installed PV capacity in 2050 between SS-NFNR and SS-AR scenarios

The results highlight the importance of solar costs and water availability in evaluating where new PV capacity could be installed. Similarly, as PV water use rates differ from other technologies that could be employed, water use impacts of scenarios can also differ national and regionally.

\subsection{National Water Use Results}

National water withdrawals and consumptive uses of water in 2050 are greatly affected by present-day trends in power plant cooling decisions, where new power plants are moving away from once-through cooling systems towards the use of lower withdrawal yet higher consumptive 
rate recirculating systems. Figure 7 highlights national levels of water withdrawals for 2010, 2030, and 2050 for all scenarios.
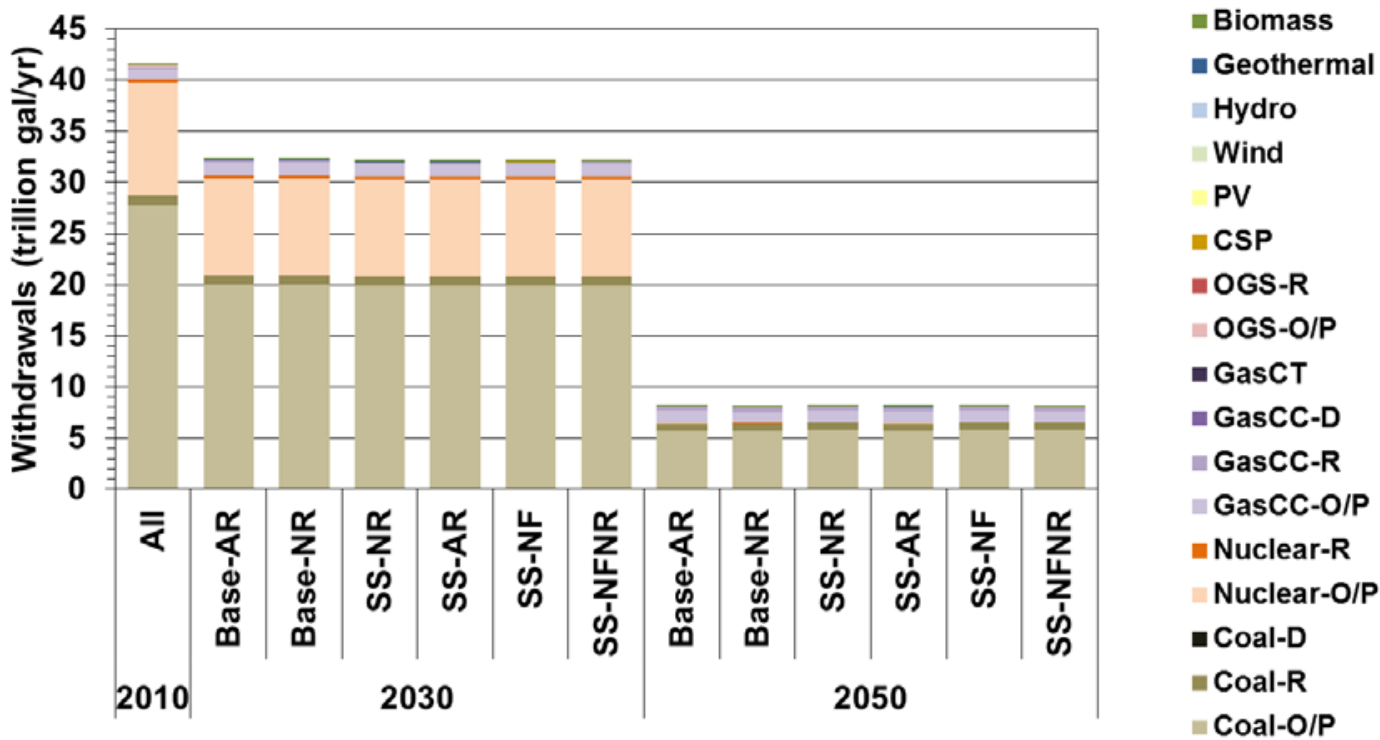

Figure 7. National water withdrawals by fuel and cooling system type in 2010, 2030, and 2050

OGS=Oil, gas steam technologies; $\mathrm{R}=$ Recirculating cooling; $\mathrm{O} / \mathrm{P}=$ Once-through and pond cooling; $\mathrm{D}=$ Dry cooling; $\mathrm{CT}=$ Combustion turbine; $\mathrm{CC}=$ Combined Cycle.

Water withdrawals are similar in all scenarios, with water withdrawals being heavily dominated by once-through cooling demands of coal, nuclear, and natural gas facilities. Water withdrawals decline from around 42 trillion gallons per year in 2010 to around 33 trillion gallons per year in 2030 to around 8 trillion gallons per year in 2050. Water withdrawals are trending downward, and solar cost scenarios and water restriction scenarios have very little impact on national levels of water withdrawals, largely due to existing thermal facilities that continue to operate through 2050 .

National water consumption trends follow a similar but less dramatic pattern to water withdrawal trends. Figure 8 highlights national water consumption for 2010, 2030, and 2050 for all scenarios. 


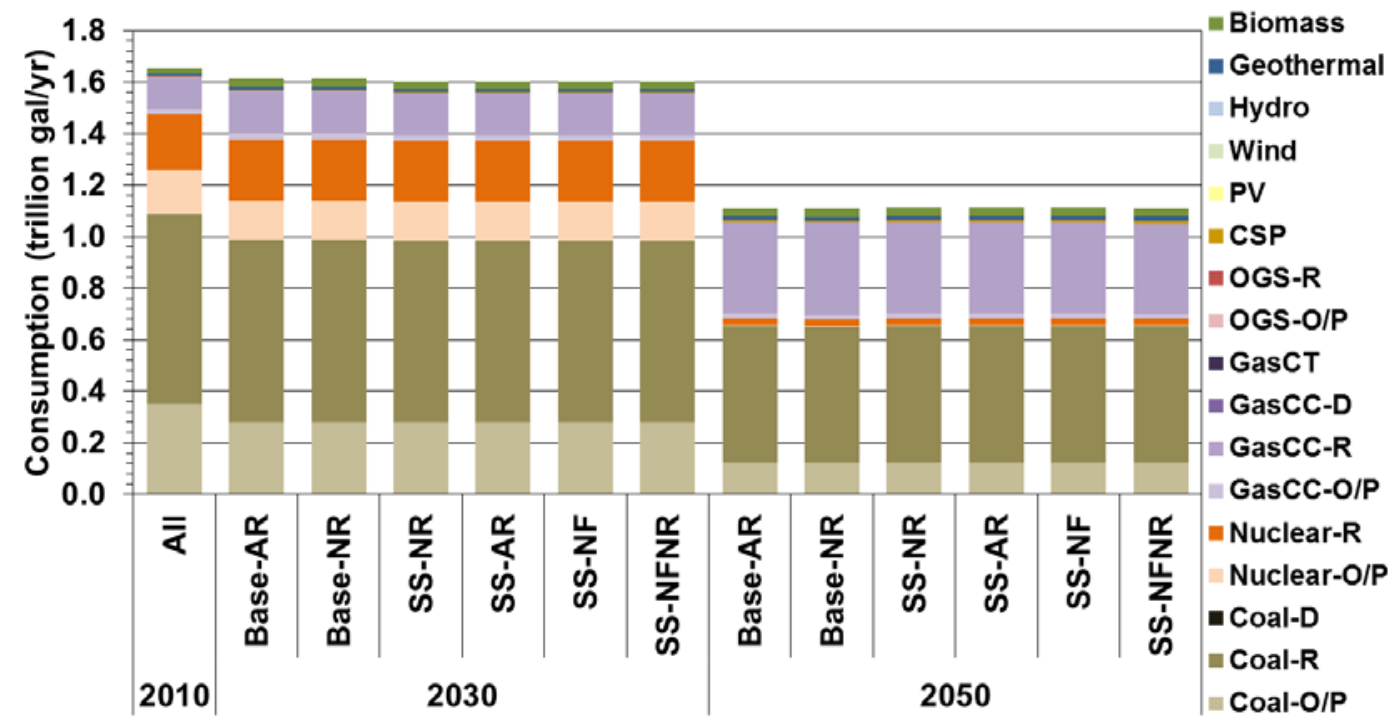

Figure 8. National water consumption by fuel and cooling system type in 2010, 2030, and 2050

OGS=Oil, gas steam technologies; $\mathrm{R}=$ Recirculating cooling; $\mathrm{O} / \mathrm{P}=$ Once-through and pond cooling; $\mathrm{D}=$ Dry cooling; $\mathrm{CT}=$ Combustion turbine; $\mathrm{CC}=$ Combined Cycle.

Water consumption is similar in all scenarios, and is dominated by coal, nuclear, and natural gas facilities that utilize recirculating cooling systems. Water consumption declines from around 1.7 trillion gallons per year in 2010 to 1.6 trillion gallons per year in 2030, and drops more precipitously to around 1.1 trillion gallons per year by 2050 . The large declines in water consumption can be attributed to high penetration of solar PV technologies and wind technologies, which require little to no water for operations, and natural gas combined cycle technologies, which have lower water requirements than retiring coal and nuclear power plants. Improved cost scenarios for PV that lead to increased PV penetration do not necessarily lead to water consumption reductions over base case PV cost scenarios, as the total level of thermal energy technology penetration in all scenarios is approximately the same. Water restriction scenarios do not affect total water consumption in these scenarios, as municipal wastewater resources can provide some water availability for new power plants and existing power plants continue operating with their existing water access.

\subsection{Regional Water Usage Results}

Water resources are managed locally and water is not easily transferred across basins. For this reason, regional impact analyses of water resource usage are essential and can provide insight into the sustainability of water use. As water resource boundaries do not follow state boundaries, analyzing water resource impacts at the watershed level is useful to water managers. The regional water usage results presented here are displayed at the 18 USGS HUC-2 watershed units.

The strong trend in declining water withdrawals and water consumption in all scenarios is persistent in the regional water use analysis. Relatively high penetration of solar PV and wind energy technologies in all scenarios combined with reductions in withdrawals associated with retiring once-through cooled coal, nuclear and natural gas steam power plants generally lead to similar withdrawal declines in each watershed unit for all scenarios. Figure 9 shows the regional 
water withdrawal comparison of the SS-AR scenario (where improved solar costs are utilized and all water resource types are available).

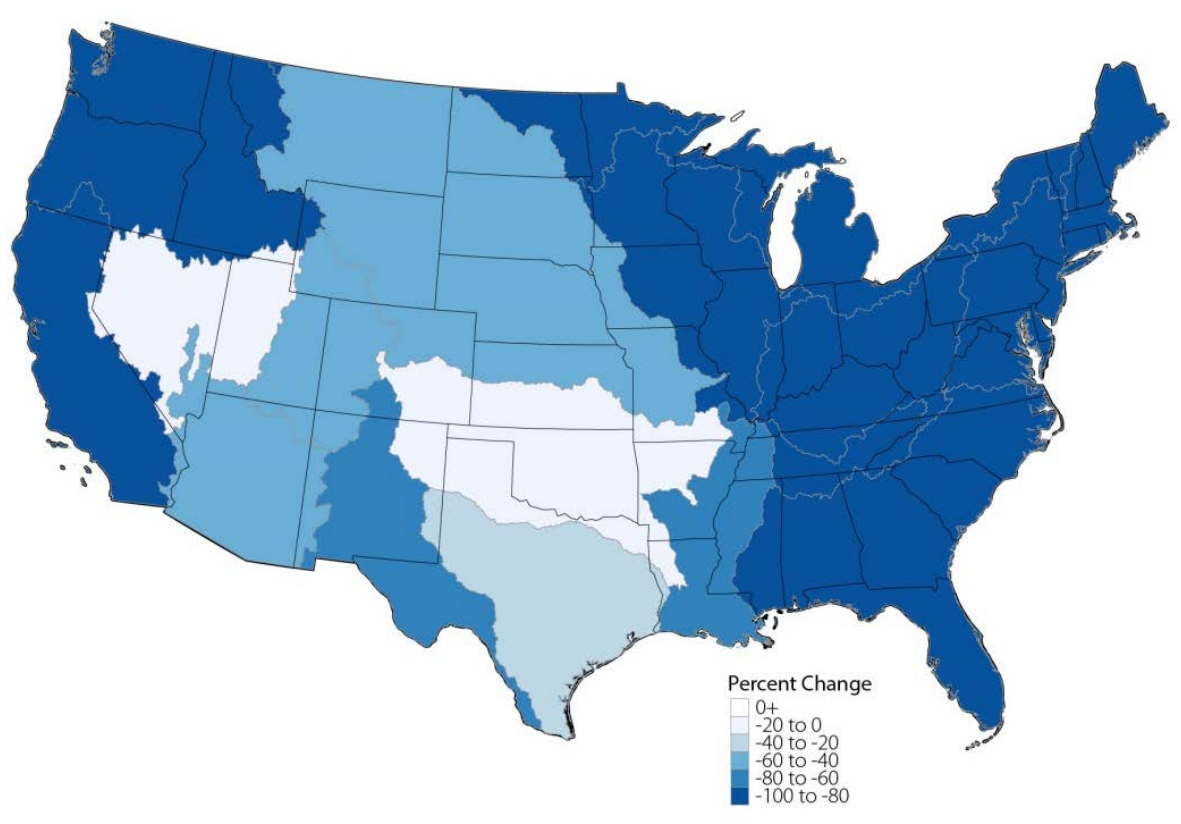

Figure 9. Comparison of water withdrawals in 2010 with those in 2050 for the SS-AR scenario

Every HUC-2 watershed unit shows declines in water withdrawals in 2050 under the SS-AR scenario as compared with 2010 withdrawals, with four regions having reductions greater than $90 \%$. Results are similar regionally for all scenarios. Relatively smaller, yet still substantial, reductions in water withdrawals are seen in the Central Plains, Texas, Nevada, and western Utah.

Water consumption declines are less dramatic than water withdrawal declines, and one region (Nevada and western Utah) shows a slight increase in 2050 under the SS-AR scenario from 2010 values (Figure 10). 


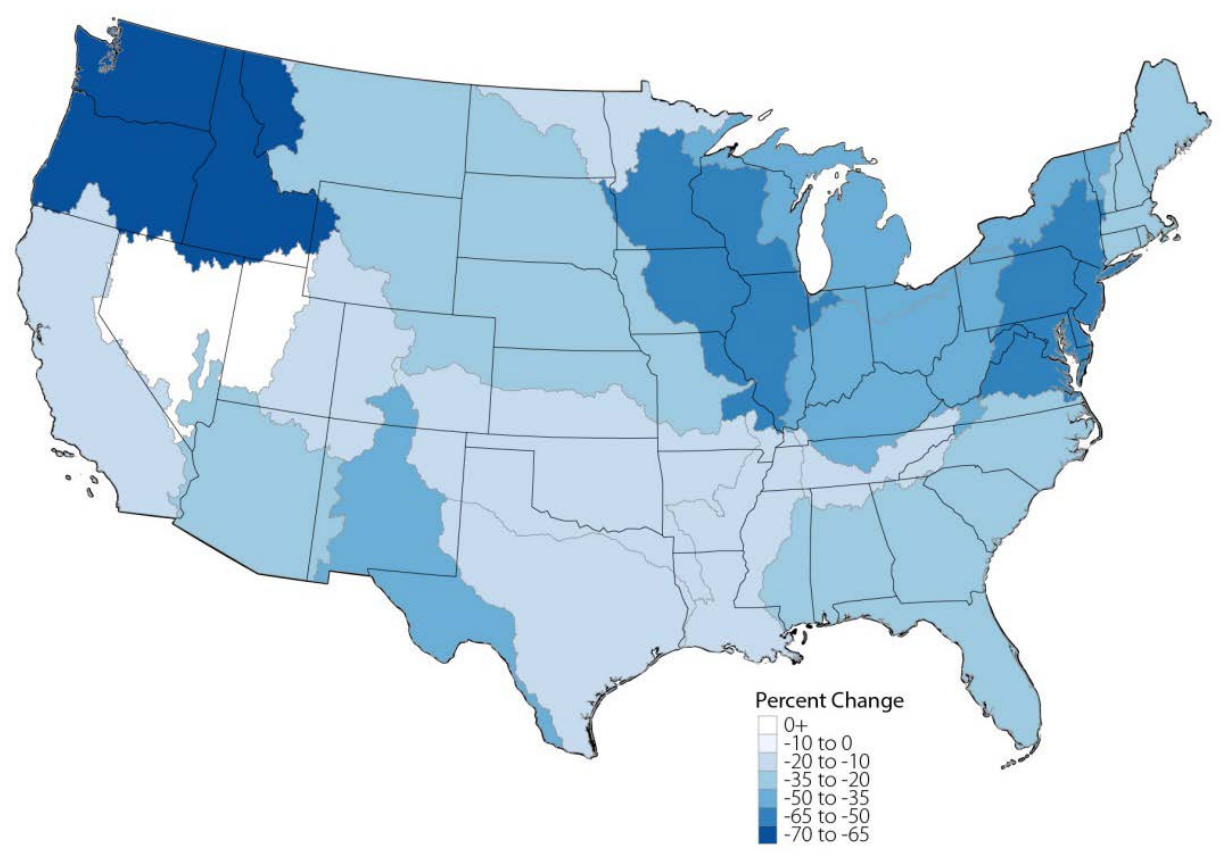

Figure 10. Comparison of water consumption in 2010 with consumption in 2050 for the SS-AR scenario

Regional results are similar across all scenarios, largely driven by the similar quantities of thermal energy (primarily natural gas) technologies built. Additional solar PV capacity built in the improved cost cases does not offset enough water-consuming thermal generation to have a large impact on watershed-level consumption beyond the large reductions already taking place due to thermal cooling technology trends and the large wind and PV installation amounts in the base case cost scenarios. 


\section{Discussion}

During the 2010-2050 study period, the water use intensity of generation sources declined because coal and nuclear dominated retirements and most new capacity came from lower waterintensity solar, wind, and natural gas technologies. Considering this overall trend, results from this work highlight the important role PV deployment can have in reducing national and regional levels of water withdrawal and consumption. The relatively small water requirements of PV systems during operation make it an effective electricity generating technology in times of drought or in arid areas. PV systems can thus be seen as a useful technology choice that could be resilient under a changing climate, where water resource availability could be variable or unreliable.

PV technology deployment is one part of a suite of electricity sector trends contributing to lower water withdrawals and consumptive uses, and there are there are multiple reasons for water use reductions in the scenarios considered. Wind energy technologies also provide electricity with little to no water required for operations; wind energy provided approximately twice as much electricity as PV in 2050 for all scenarios considered. New installations of thermal energy technologies - which favor types of power plants and cooling systems with lower water usealso contribute to declining trends in water use. Due to fuel and technology costs, natural gas combined cycle power plants dominate new thermal energy capacity additions. Natural gas combined cycle power plants have higher efficiencies than many existing thermal steam plants, and they use combustion turbine components that provide electricity without the need for water, leading to withdrawal and consumption rates that can be around half of existing coal and nuclear power plants. In addition, new power plants are being built with recirculating cooling systems, which withdraw substantially less water with a slightly higher consumption rate than existing once-through cooling systems.

High penetration of PV in the electricity system can have some limitations as a strategy to reduce regional and national water use, depending on where solar deployment occurs. In the improved cost scenarios, PV capacity installations increased by $19 \%$ over the base case cost scenarios, yet generation from PV increased by just 9\%, likely due to much of the new installed PV being located in areas with lower quality solar resources, such as the northern and southeastern parts of the country, or due to curtailments of PV when PV generation exceeds demand. With its highquality solar resources and arid climate, the southwest would seem to be a region where PV cost reduction would be more valuable than elsewhere. However, improved PV costs did not result in as much of an increase in PV capacity in the southwest as in other regions. This could be due to the saturation of PV technologies in this area or due to other low-cost generation options in this area. Regional water withdrawals and consumptive uses were virtually identical in all scenarios, as the additional PV capacity and generation in the improved cost scenarios did not substantially reduce or offset water-consuming thermal generation.

The inclusion of severe water restrictions for new electricity generating technologies had a small impact on the location of new PV technology capacity additions. The most restrictive water availability case saw its largest increases in new PV capacity in the southeastern part of the country, an area not always considered to have water shortages. In many areas, re-allocation of water resources from retiring power plants or alternative water resources provide sufficient water 
resources, for new power plants, such that PV systems do not see a large increase in deployment due to freshwater restrictions.

Limitations in this work include the diversity of cost assumptions considered, the spatial and temporal resolution of the model, and the static nature of water resources considered. Future work could improve the understanding of the role of PV in future electricity system scenarios under water and land constraints and could address certain limitations of this study. The impact of PV deployment on national and regional water usage under improved cost scenarios is somewhat muted due to the substantial cost reductions already included in the base case cost scenarios. Other technologies, such as wind and natural gas combined cycle, also had substantial cost reductions and greatly increased in deployment; lower levels of cost reductions in wind and changes in natural gas prices could affect PV deployment. For example, future work could analyze a variety of different PV cost scenarios, including less and more aggressive cost reduction pathways. Additional work could also address other limitations in this study, such as: using alternative cost scenarios for wind energy and other technologies; evaluating dynamic water resource availability that can be affected by climate change at a smaller geographic scale; considering land use requirements of PV systems and how this compares with available land and existing uses; and evaluating the resilience of the electricity system and the value of PV under various penetrations of PV during droughts or other times when water-dependent thermal generation could be affected. 


\section{Summary}

The results presented here provide insight into the national and regional water use implications of high penetration scenarios of solar PV technologies. A modified version of the ReEDS model, which has high geographic resolution and incorporates water resource availability as a constraint, was used to analyze six scenarios of varying PV technology cost and water resource availability restrictions. Results for electricity capacity as well as water withdrawal and consumption were presented on a national and regional scale. PV technologies require little to no water for operation and have an important role in reducing water usage in the electricity sector. PV technologies are one component of a number of trends that can reduce future water usage in the electricity sector, including the installation of wind technologies, the increase in natural gas combined cycle power plants, and the use of recirculating cooling systems for new powered plants. Reduced PV costs tend to increase PV deployment in areas with lower solar resource quality and in areas that are generally not considered to be water-stressed. Imposing severe restrictions on new uses of freshwater did not substantially alter the magnitude or the location of new PV installations. PV systems can operate without water and could provide important grid services in arid areas or in times of drought; future research is required to test and validate this value of PV systems. 


\section{References}

Averyt, K.; Fisher, J.; Huber-Lee, A.; Lewis, A.; Macknick, J.; Madden, N.; Rogers, J.; Tellinghuisen, S. Freshwater Use by U.S. Power Plants: Electricity's Thirst for a Precious Resource (2011) | UCSUSA; 2011.

Black \& Veatch. Cost and performance data for power generation technologies; Overland Park, KS, 2012.

Chandel, M. K.; Pratson, L. F.; Jackson, R. B. The potential impacts of climate-change policy on freshwater use in thermoelectric power generation. Energy Policy 2011, 39, 6234-6242.

Clemmer, S.; Rogers, J.; Sattler, S.; Macknick, J.; Mai, T. Modeling low-carbon US electricity futures to explore impacts on national and regional water use. Environ. Res. Lett. 2013, 8, 015004.

Electric Power Research Institute (EPRI). Use of Alternate Water Sources for Power Plant Cooling; 10014935; Electric Power Research Institute: Palo Alto, CA, 2008.

Environmental Protection Agency. Environmental and Economic Benefits Analysis for Proposed Section 316(b) Existing Facilities Rule; EPA 821-R-11-002; 2011.

Grubert, E. A.; Beach, F. C.; Webber, M. E. Can switching fuels save water? A life cycle quantification of freshwater consumption for Texas coal- and natural gas-fired electricity. Environ. Res. Lett. 2012, 7, 045801.

Hadjerioua, B.; Kao, S.; McManamy, R.; Pasha, M. An Assessment of Energy Potential from New Stream-reach Development in the United States: Initial Report on Methodology; Technical Manual 2012/298; Oak Ridge National Laboratory: Oak Ridge, TN, 2013.

Hadjerioua, B.; Wei, Y.; Kao, S. An Assessment of Energy Potential at Non-Powered Dams in the United States; GPO DOE/EE-0711; U.S. Department of Energy: Washington, DC, 2012.

Kenny, J. F.; Barber, N. L.; Hutson, S. S.; Linsey, K. S.; Lovelace, J. K.; Maupin, M. A. Estimated Use of Water in the United States in 2005; CIR - 1344; United States Geological Survey, 2009.

Li, H.; Chien, S.-H.; Hsieh, M.-K.; Dzombak, D. A.; Vidic, R. D. Escalating Water Demand for Energy Production and the Potential for Use of Treated Municipal Wastewater. Environ. Sci.

Technol. 2011, 45, 4195-4200.

Logan, J.; Lopez, A.; Mai, T.; Davidson, C.; Bazilian, M.; Arent, D. Natural gas scenarios in the U.S. power sector. Energy Econ. 2013, 40, 183-195.

Macknick, J.; Newmark, R.; Heath, G.; Hallett, K. C. Operational water consumption and withdrawal factors for electricity generating technologies: a review of existing literature. Environ. Res. Lett. 2012, 7, 045802. 
Macknick, J.; Sattler, S.; Averyt, K.; Clemmer, S.; Rogers, J. The water implications of generating electricity: water use across the United States based on different electricity pathways through 2050. Environ. Res. Lett. 2012, 7, 045803.

Macknick, J., S. Cohen, V. Tidwell, T. Woldeyesus, A. Martinez, and R. Newmark. Water constraints in an electric sector capacity expansion model; NREL/TP-6A20-64270; National Renewable Energy Laboratory: Golden, CO, 2015.

Mai, T.; Wiser, R.; Sandor, D.; Brinkman, G.; Heath, G.; Denholm, P.; Hostick, D.; Darghouth, N.; Schlosser, A.; Strzepek, K. Exploration of High Penetration Renewable Electricity Futures. Vol. 1 of Renewable Electricity Futures Study.; NREL/TP-6A20-52409-1; National Renewable Energy Laboratory: Golden, CO, 2012.

Maupin, M., Kenny, J., Hutson, S., Lovelace, J., Barber, N., Linsey, K. Estimated Use of Water in the United States in 2010; CIR - 1405; United States Geological Survey, 2014.

National Renewable Energy Laboratory (NREL). Renewable Electricity Futures Study; NREL/TP-6A20-52409; National Renewable Energy Laboratory: Golden, CO, 2012.

Rogers, J.; Averyt, K.; Clemmer, S.; Davis, M.; Flores-Lopez, F.; Kenney, D.; Macknick, J.; Madden, N.; Meldrum, J.; Sattler, S.; et al. Water-Smart Power: Strengthening the U.S. Electricity System in a Warming World (2013) | UCSUSA; 2013.

Roy, S. B.; Chen, L.; Girvetz, E. H.; Maurer, E. P.; Mills, W. B.; Grieb, T. M. Projecting Water Withdrawal and Supply for Future Decades in the U.S. under Climate Change Scenarios. Environ. Sci. Technol. 2012, 46, 2545-2556.

Saha, A. (2013). Review of Coal Retirements. M.J. Bradley \& Associates LLC.

Seaber, P. R.; Kapinos, F. P.; Knapp, G. L. Hydrologic unit maps; WSP - 2294; United States Geological Survey, 1987.

Short, W.; Sullivan, P.; Mai, T.; Mowers, M.; Uriarte, C.; Blair, N.; Heimiller, D.; Martinez, A. Regional Energy Deployment System (ReEDS); NREL/TP-6A20; National Renewable Energy Laboratory: Golden, CO, 2011.

Stillwell, A. S.; Webber, M. E. Geographic, Technologic, And Economic Analysis of Using Reclaimed Water for Thermoelectric Power Plant Cooling. Environ. Sci. Technol. 2014, 48, 4588-4595.

Tidwell, V. C.; Zemlick, K.; Klise, G. T. Nationwide Water Availability Data for Energy-Water Modeling; SAND2013-9968; Sandia National Laboratories: Albuquerque, NM, $2013 \mathrm{a}$.

Tidwell, V. C.; Malczynski, L. A.; Kobos, P. H.; Klise, G. T.; Shuster, E. Potential Impacts of Electric Power Production Utilizing Natural Gas, Renewables and Carbon Capture and Sequestration on U.S. Freshwater Resources. Environ. Sci. Technol. 2013b, 47, 8940-8947. 
U.S. Department of Energy (US DOE). 20\% Wind Energy by 2030: Increasing Wind Energy's Contribution to U.S. Electricity Supply; DOE/GO-102008-2567; U.S. Department of Energy: Washington, DC. 2010.

U.S. Department of Energy (US DOE). SunShot Vision Study. Office of Energy Efficiency and Renewable Energy. DOE/GO-102012-3037. Washington, D.C.: U.S. Department of Energy. 2012.

U.S. Department of Energy (US DOE). U.S. Billion-Ton Update: Biomass Supply for a Bioenergy and Bioproducts Industry; U.S. Department of Energy: Oak Ridge, TN, 2011.

U.S. Department of Energy (US DOE). U.S. Energy Sector Vulnerabilities to Climate Change and Extreme Weather; DOE/PI-0013; 2013.

U.S. Energy Information Administration (US EIA). Annual Energy Outlook 2013 with Projections to 2040; U.S. Energy Information Administration: Washington, DC, 2013.

Union of Concerned Scientists. UCS EW3 Energy-Water Database. V.1.3; Union of Concerned Scientists: Cambridge, MA, 2012.

Ventyx. (2013). Ventyx Energy Velocity Suite.

van Vliet, M. T. H.; Yearsley, J. R.; Ludwig, F.; Vogele, S.; Lettenmaier, D. P.; Kabat, P.

Vulnerability of US and European electricity supply to climate change. Nat. Clim Change 2012.

Watson, I.; Morin, O.; Henthorne, L. Desalting Handbook for Planners, Third Edition; Desalination Research and Development Program Report No. 72; U.S. Bureau of Reclamation, 2003.

Zhang, Q.; Martinez, R.; Smith, B. Hydropower Initital Capital Cost Modeling. In; Denver, CO, 2013. 